\title{
Administrasi Keuangan
}

\author{
Yuni Kartika Sari \\ Universitas Negeri Padang \\ Indonesia \\ E-mail : yunikartikasari446@gmail.com
}

\begin{abstract}
Abstrak-Each work unit is always related to financial problems, as well as in educational institutions. Problems relating to finance in schools generally revolve around: contributions to education (SPP), money for personnel welfare and salaries as well as finances that are directly related to the administration of schools such as repair of facilities and so on. To realize quality education, there needs to be a thorough and professional management of the resources available in educational institutions. One resource that needs to be managed properly in education is financial matters. In this context, finance is a source of funds that are urgently needed by schools as a tool to complement various learning facilities and infrastructure in schools, improve teacher welfare, services and the implementation of supervision programs.
\end{abstract}

Keywords-(Administrasi Keuangan)

\section{Pendahuluan}

Setiap unit kerja selalu berhubungan dengan masalah keuangan, demikian pula di lembaga pendidikan. Soal-soal yang menyangkut keuangan di sekolah pada garis besarnya berkisar pada: uang sumbangan pembinaan pendidikan (SPP), uang kesejahteraan personil dan gaji serta keuangan yang berhubungan langsung dengan penyelenggaraan sekolah seperti perbaikan sarana dan sebagainya.

Untuk mewujudkan pendidikan yang berkualitas, perlu adanya pengelolaan secara menyeluruh dan professional terhadap sumber daya yang ada dalam lembaga pendidikan. Salah satu sumber daya yang perlu dikelola dengan baik dalam pendidikan adalah masalah keuangan. Dalam konteks ini, keuangan merupakan sumber dana yang sangat diperlukan sekolah sebagai alat untuk melengkapkkan berbagai sarana dan prasarana pembelajaran di sekolah, meningkatkan kesejahteraan guru, layanan dan pelaksanaan program supervisi.

Setiap kegiatan perlu diatur agar kegiatanberjalan tertib, lancar, efektif dan efisien. Kegiatan di sekolah yang sangatkompleks termasuk kegiatan keuanganjuga membutuhkan pengaturan yang baik.Keuangan di sekolah merupakan bagian yang amat penting karena setiap kegiatanbutuh uang. Keuangan juga perlu diatur sebaikbaiknya, sehingga disekolah perlumanajemen keuangan yang baik. Sebagaimana yang terjadi di substansi manajemen pendidikan pada umumnya,kegiatan manajemen keuangan dilakukan melalui proses perencanaan,pengorganisasian, pengarahan, pengkoordinasian, pengawasan atau pengendalian.

Beberapa kegiatan manajemen keuangan yaitu memperoleh dan menetapkan sumber-sumber pendanaan, pemanfaatan dana, pelaporan, pemeriksaan dan pertanggungjawaban.Di dalam manajemen keuangan sekolah terdapat rangkaian aktivitas terdiri dariperencanaan program sekolah, perkiraan anggaran, dan pendapatan yang diperlukandalam pelaksanaan program, pengesahan dan penggunaan anggaran sekolah.

Sebagai suatu lembaga pendidikan perlu ditingkatkan dan disesuaikan denagan kebutuhan dan perkembangan pembangunan disegala bidang baik segi sarana dan prasarana Pendidikan, fasilitas kerja maupun kesejahtraan yang layak bagi seluruh tenaga Pendidik. Untuk memenuhi sasaran tersebut sangat diperlukan biaya yang cukup dan administrasi yang tertib

Dalam penyeleggaraan pendidikan, keuangan dan pembiayaan merupakan potensi yang sangat menentukan dan merupakan bagian yang tak terpisahkan dalam kajian administrasi dan manajemen pendidikan. Komponen pembiayaan dan keuangan pada tingat satuan pendidikan merupakn komponen produksi yang menentukan proses terlaksananya kegiatan-kegiatan proses belajar-mengajar di sekolah bersama komponen-komponen lain. Dengan kata lain, setiap kegiatan yang dilakukan sekolah memerlukan biaya, baik disadari maupun tidak.

Komponen keuangan dan pembiayaan ini perlu dikelola sebaik-baiknya agar dana yang ada dapat dimanfaatan secara optimal untuk menunjang tercapainya tujuan pendidikan. Hal ini penting, terutama dalam rangka implementasi Manajemen Berbasis Sekolah, yang memberikan kewenangan sekolah untuk mencari dan memanfaatkan berbagai sumber dana sesuai dengan keperluan sekolah. Disebabkan pada umumnya dunia pendidikan selalu dihadapkan pada masalah keterbatasan dana. Apalagi dalam berbagai kondisi pereokonomian dunia yang sedag dilanda krisis.

Berdasarkan pemikiran di atas, pengelolaan keuangan pendidikan lebih difokuskan dalam proses merencanakan alokasi secara teliti dan penuh perhitungan serta mengawasi pelaksanaan dana, bak biaya operasional maupun biaya kapital, disertai bukti-bukti secara administratif dan fisik (material) sesuai dengan dana yang dikeluarkan.

\section{Metode PENELITIAN}

Artikel ilmiah seharusnya disusun dengan metode dan langkah-langkah yang sistematis. Pada artikel ini, penulis menggunakan metode mengumpulkan bahan dan materi dari buku, jurnal, artikel, dan sumber lain yang berkaitan dengan administrasi keuangan. Metode literatur yang berhubungan 
dengan topik yang diminati dapat membantu mempermudah dalam merumuskan masalah penelitian, metode ini disebut juga dengan metode SLR (Systematic Literature Review). Setelah bahan kajian dan materi dikumpulkan, kemudian diteliti. Penulis nantinya menyimpulkan pengetahuan yang penulis dapatkan dari materi tersebut. Metode literatur ini bertujuan untuk membantu menemukan wawasan, kebenaran dan juga penyelesaian dari masalah yang dihadapi. Sebagai petunjuk yang terbukti kebenarannya sebaiknya menggunakan buku-buku dengan tanngal hak cipta baru. Semakin baru sebuah buku ditulis maka semakin cocok dengan zaman dari materi yang akan ditelaah/dipelajari.

\section{KAJIAN TEORI DAN PEMBAHASAN}

\section{A. Pengertian Administrasi Keuangan}

Keuangan adalah semua hak milik organisasi, lembaga atau instansi yang dapat dinilai dengan uang, termasuk didalamnya barang yang dapat dinilai dengan uang dan dapat dijadikan milik organisasi. Sedangkan uang adalah alat pembayaran Negara.

Manajemen keuangan merupakan salah satu substansi manajamen sekolah yang akan turut menentukan berjalannya kegiatan pendidikan di sekolah. Sebagaimana yang terjadi di substansi manajemen pendidikan pada umumnya, kegiatan manajemen keuangan dilakukan melalui proses perencanaan, pengorganisasian, pengarahan, pengkoordinasian, pengawasan atau pengendalian.

Menurut Ubben, Hughes \& Norris (dalam Nurhizrah Gistituati, 2012: 150) kegiatan menajemen keuangan sekolah cukup variatif, mulai dari yang sangat sederhana, yaitu perencanaan keuangan yang sangat sederhana, sampai pada pengelolaan keungangan yang sangat kompleks, akibat dari perencanaan kegiatan yang kompleks.

Beberapa kegiatan manajemen keuangan yaitu memperoleh dan menetapkan sumber-sumber pendanaan, pemanfaatan dana, pelaporan, pemeriksaan dan pertanggungjawaban(Lipham, 1985; Keith, 1991).

Menurut Depdiknas (2000) bahwa manajemen keuangan merupakan tindakan pengurusan/ketatausahaan keuangan yang meliputi pencatatan, perencanaan, pelaksanaan, pertanggungjawaban dan pelaporan Dengan demikian, manajemen keuangan sekolah dapat diartikan sebagai rangkaian aktivitas mengatur keuangan sekolah mulai dari perencanaan, pembukuan, pembelanjaan, pengawasan dan pertanggung-jawaban keuangan sekolah.

Pembiayaan pendidikan hendaknya dilakukan secara efisien. Makin efisien suatu sistem pendidikan, semakin kecil dana yang diperlukan untuk pencapaian tujuan-tujuan pendidikan. Untuk itu, bila sistem keuangan sekolah dikelola secara baik akan meningkatkan efisiensi penyelenggaraan pendidikan. Artinya, dengan anggaran yang tersedia, dapat mencapai tujuan-tujuan pendidikan secara produktif, efektif, efisien, dan relevan antara kebutuhan di bidang pendidikan dengan pembangunan masyarakat. Untuk mencapai hal-hal seperti di atas maka diperlukan adanya proses merencanakan, mengorganisasikan, mengarahkan, mengkoordinasikan, mengawasi, dan melaporkan kegiatan bidang keuangan agar tujuan sekolah dapat tercapai secara efektif dan efisien. Melalui kegiatan manajemen keuangan maka kebutuhan pendanaan kegiatan sekolah dapat direncanakan, diupayakan pengadaannya, dibukukan secara transparan, dan digunakan untuk membiayai pelaksanaan program sekolah secara efektif dan efisien. Untuk itu tujuan manajemen keuangan adalah:

\section{a. Meningkatkan efektivitas dan efisiensi penggunaan keuangan sekolah \\ b. Meningkatkan akuntabilitas dan transparansi keuangan sekolah. \\ c. Meminimalkan penyalahgunaan anggaran sekolah.}

Untuk mencapai tujuan tersebut, maka dibutuhkan kreativitas kepala sekolah dalam menggali sumber-sumber dana, menempatkan bendaharawan yang menguasai dalam pembukuan dan pertanggung-jawaban keuangan serta memanfaatkannya secara benar sesuai peraturan perundangan yang berlaku.

Dalam menajeman keuangan sekolah terdapat rangkaian kegiatan yang dimulai dengan perencanaan, yaitu merencanakan program kegiatan dan memperkirakan, serta menetapkan anggaran pendapatan keuangan sekolah, penggunaan anggaran sokolah sesuai dengan perencanaan sekolah, pengawasan atau pengendalian penggunaan keuangan sekolah, dan pertanggungjawaban penggunaan, serta pelaporannya. Sebagaimana yang dikemukakan oleh Depdiknas (2002), menajemen keuangan adalah tindakan pengurusan atau ketatausahaan keuangan yang meliputi perencanaan, pelaksanaan dan pencatatan, pertanggungjawaban dan pelaporan keuangan.Dengan demikian, menajemen keuangan sekolah merupakan rangkaian aktivitas mengatur keuangan sekolah mulai dari perencanaan, pembukuan, pembelajaran, pengawasan, pertanggungjawaban dan pelaporan keuangan sekolah.

a. Tujuan Menajemen Keungan Sekolah

Meningkatkan efektifitas dan efisiensi penggunaan keuangan sekolah.

Meningkatkan akuntabilitas dan transparansi keuangan sekolah.

Meminimalkan penyalahgunaan anggaran sekolah.

b. Prinsip-prinsip keuangan sekolah

Prinsp transparan

Mengandung makna bahwa dalam pengelolaan keuangan sekolah harus ada keterbukaan, dalam artian memberikan informasi yang jelas kepada pihak-pihak yang berkepentingan tantang dari mana sumber data diperoleh, berapa jumlahnya, untuk apa dana itu digunakan dan bagaimana rincian penggunaannya, serta pertanggungjawabannya.

Prinsip efisiensi

Penggunaan sumber daya keuangan yang ada harus betul-betul tapat guna, yaitu sesuai antara yang dikeluarkan dengan yang dihasilkan. Dengan kata lain penggunaan sumber daya keuangan sekolah harus bujak dan hemat. Efisiensi 
biasanya diukur dengan membandingkan antara masukan atau yang digunakan dengan yang dikeluarkan atau yang dihasilkan Prinsip Akuntabilitas

Keuangan adalah semua hak yaitu hak milik organisasi, lembaga atau instansi yang dapat dinilai dengan uang, termasuk didalamnya adalah segala sesuatu yang berupa uang atau barang yang dapat dinilai dengan uang dan dapat dijadikan milik organisasi yang karena hak atau kewajiban menjadi milik organisasi. Sedangkan uang adalah alat pembayaran Negara.

Menurut Ubben, Hughes \& Norris (dalam Nurhizrah Gistituati, 2012: 150) kegiatan menajemen keuangan sekolah cukup variatif, mulai dari yang sangat sederhana, yaitu perencanaan keuangan yang sangat sederhana, sampai pada pengelolaan keungangan yang sangat kompleks, akibat dari perencanaan kegiatan yang kompleks.

Menurut Keith \& Gurling, Swanson \& King, dan Ubben, Hughes \& Noris (dalam Nurhizrah Gistituati, 2012: 150) berhubungan dengan masalah bagaimana memperoleh dan menetapkan sumber-sumber pendanaan, memanfaatkan dana, mengendalikan dan mempertanggungajawabkan, serta melaporkannya.

Dalam menajeman keuangan sekolah terdapat rangkaian kegiatan yang dimulai dengan perencanaan, yaitu merencanakan program kegiatan dan memperkirakan, serta menetapkan anggaran pendapatan keuangan sekolah, penggunaan anggaran sokolah sesuai dengan perencanaan sekolah, pengawasan atau pengendalian penggunaan keuangan sekolah, dan pertanggungjawaban penggunaan, serta pelaporannya. Sebagaimana yang dikemukakan oleh Depdiknas (2002), menajemen keuangan adalah tindakan pengurusan atau ketatausahaan keuangan yang meliputi perencanaan, pelaksanaan dan pencatatan,

pertanggungjawaban dan pelaporan keuangan. Dengan demikian, menajemen keuangan sekolah merupakan rangkaian aktivitas mengatur keuangan sekolah mulai dari perencanaan, pembukuan, pembelajaran, pengawasan, pertanggungjawaban dan pelaporan keuangan sekolah.

Penyelenggaraan kegiatan pendidikan memerlukan adanya dana. Pemimpin pendidikan perlu mengetahui dan mempelajari peraturan - peraturan yang berlaku mengenai penggunaan, pertanggungjawaban, cara-cara penyimpanan, pembukuan dan banyak lagi aspek lainnya mengenai keuangan. Administrasi keuangan dapat dilihat dalam dua pengertian : 1. Administrasi keuangan dalam arti sempit, yaitu segala pencatatan masuk dan keluarnya keuangan untuk membiayai suatu kegiatan organisasi kerja yang berupa tata usaha atau tata pembukuan keuangan. 2. Administrasi keuangan dalam arti luas, yaitu kebijakan dalam pengadaan dan penggunaan keuangan untuk mewujudkan kegiatan organisasi kerja yang berupa kegiatan perencanaan, pengaturan , pertanggungjawaban, dan pengawasan keuangan. Penyusunan anggaran disusun dalam bentuk Anggaran Pendapatan dan Belanja Negara (APBN) di tingkat pusat dan Anggaran dan Pendapatan Belanja Daerah (APBD) untuk tingkat wilayah atau daerah. APBN terdiri atas dua jenis anggaran, yaitu anggaran rutin dan anggaran pembangunan. Anggaran ruti adalah dana APBN yang diperuntukkan bagi kegiatan rutin. Kegiatan rutin ini meliputi kegiatan yang berlangsung setiap tahun, seperti gaji, biaya kanor, biaya telepon, biaya pemeliharaan gedung, dan sebagainya. Anggaran adalah suatu rencana keuangan yang disusun untuk perencanaan suatu kegiatan dalam jangka waktu tertentu, biasanya untuk satu tahun. Perputaran tahun anggaran disebut budget cyclus . Prosesnya meliputi fase perencanaan, fase pelaksanaan, dan fase pertanggung jawaban.

\section{B. Proses Administrasi Keuangan}

\section{1) Penyusunan RPS}

Rencana Pengembangan Sekolah (RPS) merupakan salah satu wujud dari salah satu fungsi manajemen sekolah yang amat penting, yang harus dimiliki sekolah untuk dijadikan sebagai panduan dalam menyelenggarakan pendidikan di sekolah, baik untuk jangka panjang (20 tahun), menengah (5 tahun) maupun pendek (satu tahun).

Rencana Pengembangan Sekolah (RPS) memiliki fungsi amat penting guna memberi arah dan bimbingan bagi para pelaku sekolah dalam rangka pencapaian tujuan sekolah yang lebih baik (peningkatan, pengembangan) dengan resiko yang kecil dan untuk mengurangi ketidakpastian masa depan. Standar Nasional Pendidikan (standar kelulusan, kurikulum, proses, pendidikan dan tenaga kependidikan, sarana dan prasarana, pembiayaan, pengelolaan, dan penilaian pendidikan) merupakan substansi penting dalam sistem pengelolaan sekolah yang harus direncanakan sebaik-baiknya dan diakomodir dalam penyusunan Rencana Pengembangan Sekolah.

Atas dasar itu, Depdiknas telah menyiapkan sebuah panduan teknis bagi sekolah dalam penyusunan Rencana Pengembangan Sekolah, yang disampaikan oleh Prof. Slamet PH. MA, MEd, MA, MLHR, Ph.D, yang mengupas tentang:

a. Pentingnya Rencana Pengembangan Sekolah (RPS). RPS penting dimiliki untuk memberi arah dan bimbingan para pelaku sekolah dalam rangka menuju perubahan atau tujuan sekolah yang lebih baik (peningkatan, pengembangan) dengan resiko yang kecil dan untuk mengurangi ketidakpastian masa depan.

b. Arti Perencanaan Sekolah/RPS.Perencanaan sekolah adalah suatu proses untuk menentukan tindakan masa depan sekolah yang tepat, melalui urutan pilihan, dengan memperhitungkan sumberdaya yang tersedia.RPS adalah dokumen tentang gambaran kegiatan sekolah di masa depan dalam rangka untuk mencapai perubahan/tujuan sekolah yang telah ditetapkan.

c. Tujuan Rencana Pengembangan Sekolah (RPS). RPS disusun dengan tujuan untuk: (1) menjamin agar perubahan/tujuan sekolah yang telah ditetapkan dapat dicapai dengan tingkat kepastian yang tinggi dan resiko yang kecil; (2) mendukung koordinasi antar pelaku sekolah; (3) menjamin terciptanya integrasi, sinkronisasi, dan sinergi baik antar pelaku sekolah, antarsekolah dan dinas pendidikan kabupaten/kota, dan antarwaktu 
d. Sistem Perencanaan Sekolah (SPS). Sistem Perencanaan Sekolahadalah satu kesatuan tata cara perencanaan sekolah untuk meng-hasilkan rencana-rencana sekolah (RPS) dalam jangka panjang, jangka menengah, dan tahunan yang dilaksanakan oleh unsur penyelenggara sekolah dan masyarakat (diwakili oleh komite sekolah).

e. Tahap-tahap Penyusunan Rencana Pengembangan Sekolah (RPS), mencakup:

a) Melakukan analisis lingkungan strategis sekolah;

b) Melakukan analisis situasi untuk mengetahui status situasi pendidikan sekolah saat ini (IPS);

c) Memformulasikan pendidikan yang diharapkan di masa mendatang;

d) Mencari kesenjangan antara butir $2 \& 3$;

e) Menyusun rencana strategis;

f) Menyusun rencana tahunan;

g) Melaksanakan rencana tahunan; dan

h) Memonitor dan mengevaluasi.

\section{2) Penyusunan RKAS}

Tujuan penyusunan RKAS

a. Memberikan arah yang jelas terhadap program sekolah

b. Merencanakan kegiatan-kegiatan sekolah di masa yang akan datang

c. Menjamin tercapainya integrasi, sinkronisasi, dan sinergi pendanaan pada kegiatan-kegiatan sekolah.

d. Menjamin keterkaitan dan konsistensi antara perencanaan penganggaran, pelaksanaan dan pengawasan.

e. Mengoptimalakan partisipasi warga sekolah dan masyarakat dan hal dukungan dan pengawasan.

f. Mengoptimalkan partisipasi warga sekolah dan masyarakat beserta hal dukungan financial.

g. Menjamin tercapainya penggunaan sumber dana secara efisien, efektif, berkeadilan, dan berkesinambungan.

Beberapa ketentuan perlu diperhatikan dalam penyusunan RKAS. Ketentuan yang paling mendasar isinya tidak boleh menyimpang dari RKAS. Ketentuan lainnya dalam penyusunan RKAS yaitu:

a. Menggunakan strategi analisis SWOT

b. Analisis SWOT dilakukan setiap tahun

c. RKAS merupakan penjabaran dari RKS

d. Program yang direncanakan bersifat lebih operasional

e. Ada benang merah antara tujuan empat tahunan dan sasaran (tujuan situasional) satu tahunan

f. Rencana dan program sekolah harus memperhatikan hasil analisis SWOT.

Ada beberapa langkah-langkah penyusunan RKAS dalam adninistrasi keuangan adalah sebagai berikut:

a. Melakukan analisis lingkungan operasional sekolah

b. Melakukan analisis pendidikan sekolah saat ini

c. Melakukan analisis pendidikan sekolah satu tahun ke depan (yang diharapkan)

d. Menentukan kesenjangan antara situasi sekolah saat ini dan yang diharapkan satu tahun kedepan. e. Merumuskan tujuan sekolah selama satu tahun ke depan (disebut juga dengan sasaran atau tujuan situasional satu tahun).

f. Mengidentifikasi fungsi-fungsi atau urusan-urusan sekolah untuk dikaji tingkat kesiapannya

g. Melakukan analisis SWOT

h. Merumuskan dan mengidentifikasi Alternatif Langkah-langkah Pemecahan Persoalan

i. Menyusun Rencana Program

j. Menentukan tonggak-tonggak kunci keberhasilan/output apa dan kapan dicapai (milestone)

k. Menyusun rencana biaya (besar dana, alokasi, sumber dana)

1. Menyusun rencana pelaksanaan program

m. Menyusun rencana pemantauan dan evaluasi

n. Membuat jadwal pelaksanaan program

o. Menentukan penanggungjawab program/kegiatan

3) Pertanggungjawaban Keuangan Sekolah

Tanggung jawab yang paling penting dari menajer sekolah terhadap pemerintah, dan juga terhadap komite sekolah, masyarakat, serta guru-guru adalah laporan mengenai kondisi keungan sekolah (Rebore \& Rebore dalam Narhizrah,2013:185).

Penerimaan dan pengeluaran keuangan sekolah harus dilaporkan dan dipertanggungjawabkan secara rutin oleh manajer sekolah sesuai dengan peraturan yang berlaku. Pelaporan dan pertanggungjawaban anggaran yang berasal dari orang tua peserta didik dan masyarakat dilakukan secara rinci dan transparan sesuai dengan sumber dana. Pelaporan dan pertanggungjawaban anggaran yang berasal dari usaha mandiri sekolah dilakukan lainnya.

Laporan pertanggungjawaban keungan ini penting, agar pemerintah atau masyarakat pemberi dana tahu untuk apa saja uang yang telah diberikan ke sekolah dimanfaatkan, apakah kegiatan yang didukung oleh dana tersebut terlaksana atau terimplementasikan sebagaimana yang direncanakan, serta bagaimana hasil kegiatan yang didukung oleh dana tersebut, dan bagaimana dampaknya terhadap pelaksanaan tugas utama sekolah, yaitu pembelajaran peserta didik.

Pertanggung jawaban anggaran rutin, pembangunan, dan PNBP dilakkukan dengan memperhatikan ketentuan sebagai berikut:

a. Selambat-lambatnya tanggal 10 setiap bulan bendaharawan mengirimkan surat pertanggungjawaban (SPJ) kepada wali kota/ bupati melalui bagian keuangan secretariat daerah.

b. Apabila tanggal 10 bulan berikutnya SPJ belum diterima oleh bagian keuangan secretariat daerah, maka tanggal 11 dikirimkan surat peringatan I.

c. Apabila sampai dengan tanggal 20 bulang berkikutnya SPJ juga belum dikirimkan pada bagian keuangan secretariat daerah, maka dibuatkan surat peringatan II.

d. Kelengkapan lampiran SPJ:

Surat pengantar

Sobekan BKU lembar 2 dan 3 
- Daftar penerimaan dan pengeluaran per pasal/komponen

- Daftar penerimaan dan pengeluaran UUDP.

- Laporan keadaan Kas rutin/ pembangunan (LKKR/LKKP) table I dan II.

- $\quad$ Register penutupan kas setiap 3 bulan sekali

Forokopi SPMU beban tetap dan beban sementara

Fotokopi rekening Koran dari bank yang ditunjuk

Daftar perincian penerimaan dan pengeluaran pajak

Bukti setor PPN/PPH 21, 22, 23 (forocopi SSP)

Daftar realisasi penerimaan dan pengeluaran pajak

Bukti pengeluaran/ kuitansi asli dan lembar II beserta dengan bukti pendukung lainnya, disusun per digit/ komponen.

e. Bukti pendukuang / lampiran SPJ:

Biaya perjalanan dinas dilampiri

Kuitansi / bukti pengeluaran uang.

Surat perintah tugas (SPT).

Surat perintah perjalanan dinas ( SPPD) lembar I dan II.

Penunjukan lansung barang dan jasa

Sampai dengan Rp 1. 000.000,- dilampiri kuitansi dan faktur pajak.

Pembelian di atas Rp. 1.000.000,- sampai dengan Rp 5.000.000,- dilampiri: surat penawaran, surat pesanan, kuitansi, faktur pajak, berita acara serah terima/ penyelesaian pekerjaan.

Pembelian diatas Rp 5.000.000,- sampai dengan Rp 15.000.000,- dilampiri: surat penawaran, surat penunjukan pelaksanaan pekerjaan, surat perintah kerja (SPK), berita acara pemeriksaan barang, kuitansi, faktur/nota, berita acara serah terima/ penyelesaian pekerjaan, pemimpin proyek/ atasan langsung bendaharawan diwajibkan menyusun/ melampirkan OE/HPS sebagai acuan melakukan negoisasi baik harga maupun kualitas barang/jasa yang dibutuhkan.

4) Perencanaan dan Pembuatan Anggaran

Di dalam membuat perencanaan keuangan sekolah, ada beberapa hal yang harus diperhatikan:

a. Perencanaan keuangan sekolah harus disesuaikan dengan rencana pengembangan sekolah, baik jangka panjang, jangka menengah, dan jangka pendek.

b. perencanaan keuangan sekolah harus komprehensif, artinya adalah perencanaan keuangan sekolah harus mencakup semua sumber keuangan yang ada, dan aktifitas sekolah yang akan dilakukan. dalam hal ini yang harus dilakukan adalah menganalisis semua program kegiatan dan prioritasnya, menganalisis dana yang ada dan yang mungkin bisa diadakan dari berbagai sumber pendapatan, dan dari berbagai kegiatan.

c. perencanaan keuangan sekolah harus seimbang antara pengerluaran dengan pemasukan. jangan samapi pengeluaran lebih besar dari pemasukan.

\section{Pemeriksaan dan Pelaporan}

1. Pemeriksaan Keuangan

Pemeriksaan keuangan adalah rangkaian perbuatan penelitian atas penggunan faktor dalam proses administrasi sebagaimana ditetapkan dalam jumlah anggaran, untuk menjamin penggunaan faktor uang tersebut sah dan efisien.

Agar pelaksanaan anggaran sesuai dengan ketentuannya dan tidak timbul ketekoran baik pada anggaran organisasi sebagai keseluruhan maupun anggaran bagianbagiannya, sebelum uang itu dikeluarkan atau diterima, maka dilakukan pengawasan. Pengawasan tersebut dinamakan "preventieve begrootings bewaking" (penjagaan anggaran terlebih dahulu). Dengan rumusan yang lain dinyatakan bahwa pre audit demikian ini dimaksudkan:

a Dari segi maksudnya diharapkan pelaksanaan anggaran sesuai dengan ketentuan-ketentuan atau maksud-maksudnya

b Dari segi sahnya pengeluaran uang apakah tuntutan uang itu sebagai realisasi anggaran ada dasar hukunya dan akpakah tanda-tanda bukti yang diperluakan dibuat dengan sesungguhnya dan bukti-bukti mempunyai kekuatan hukum yang cukup

c Dari segi teknis anggarannya, apakah pengeluaran dan penerimaan uang itu disediakan mata anggarannya dan termasuk dalam tahun dinas itu.

Ukuran pemeriksaan ialah apakah cara Pemerintah menggunakan uang belanja telah sepadan dengan persetujuan DPR. Untuk menjamin sah dan efisiensi penggunaan uang Negara, frekuensi pemeriksaan keuangan baik pre audit maupun post audit harus ditingkatkan. (Pariata Westra, 1980:60)

Perlu adanya koordinasi, integrasi dan sinkronisasi pemeriksaan keuangan dari semua aparat pemeriksaan keuangan, sehingga timbul efektivitas dan efisiensi pemeriksaan keuangan; disamping tidak merepotkan aparat pelaksana anggaran dalam melakukan tugasnya melaksanakan anggaran.

2. Pelaporan dan Pertanggungjawaban Keuangan Sekolah

Tanggung jawab yang paling penting dari menajer sekolah terhadap pemerintah, dan juga terhadap komite sekolah, masyarakat, serta guru-guru adalah laporan mengenai kondisi keungan sekolah (Rebore \& Rebore dalam Narhizrah.2013:185).

Penerimaan dan pengeluaran keuangan sekolah harus dilaporkan dan dipertanggungjawabkan secara rutin oleh manajer sekolah sesuai dengan peraturan yang berlaku. Pelaporan dan pertanggungjawaban anggaran yang berasal dari orang tua peserta didik dan masyarakat dilakukan secara rinci dan transparan sesuai dengan sumber dana. Pelaporan dan pertanggungjawaban anggaran yang berasal dari usaha mandiri sekolah dilakukan lainnya.

Laporan pertanggungjawaban keungan ini penting, agar pemerintah atau masyarakat pemberi dana tahu untuk apa saja uang yang telah diberikan ke sekolah dimanfaatkan, apakah kegiatan yang didukung oleh dana tersebut terlaksana atau terimplementasikan sebagaimana yang direncanakan, serta bagaimana hasil kegiatan yang didukung oleh dana 
tersebut, dan bagaimana dampaknya terhadap pelaksanaan tugas utama sekolah, yaitu pembelajaran peserta didik.

Pertanggung jawaban anggaran rutin, pembangunan, dan PNBP dilakkukan dengan memperhatikan ketentuan sebagai berikut:

a Selambat-lambatnya tanggal 10 setiap bulan bendaharawan mengirimkan Surat Pertanggungjawaban (SPJ) kepada Wali Kota/ Bupati melalui bagian Keuangan Secretariat Daerah.

b Apabila tanggal 10 bulan berikutnya SPJ belum diterima oleh bagian Keuangan Secretariat Daerah, maka tanggal 11 dikirimkan Surat Peringatan I.

c Apabila sampai dengan tanggal 20 bulang berkikutnya SPJ juga belum dikirimkan pada bagian Keuangan Secretariat Daerah, maka dibuatkan Surat Peringatan II.

d Kelengkapan lampiran SPJ:

- $\quad$ Surat pengantar

- $\quad$ Sobekan BKU lembar 2 dan 3

- Daftar penerimaan dan pengeluaran per pasal/komponen

Daftar penerimaan dan pengeluaran UUDP.

Laporan keadaan Kas rutin/ pembangunan (LKKR/LKKP) table I dan II.

Register penutupan KAS setiap 3 bulan sekali

Forokopi SPMU beban tetap dan beban sementara

Fotokopi rekening Koran dari bank yang ditunjuk

Daftar perincian penerimaan dan pengeluaran pajak

Bukti setor PPN/PPH 21, 22, 23 (forocopi SSP)

Daftar realisasi penerimaan dan pengeluaran pajak

Bukti pengeluaran/ kuitansi asli dan lembar II beserta dengan bukti pendukung lainnya, disusun per digit/ komponen.

e Bukti pendukuang / lampiran SPJ:

Biaya perjalanan dinas dilampiri

Kuitansi / bukti pengeluaran uang.

Surat perintah tugas (SPT).

Surat perintah perjalanan dinas ( SPPD) lembar I dan

II.

Penunjukan lansung barang dan jasa

Sampai dengan Rp 1. 000.000,- dilampiri kuitansi dan faktur pajak.

Pembelian di atas Rp. 1.000.000,- sampai dengan Rp 5.000.000,- dilampiri: surat penawaran, surat pesanan, kuitansi, faktur pajak, berita acara serah terima/ penyelesaian pekerjaan.

Pembelian diatas Rp 5.000.000,- sampai dengan Rp 15.000.000,- dilampiri: surat penawaran, surat penunjukan pelaksanaan pekerjaan, surat perintah kerja (SPK), berita acara pemeriksaan barang, kuitansi, faktur/nota, berita acara serah terima/ penyelesaian pekerjaan, pemimpin proyek/ atasan langsung bendaharawan diwajibkan menyusun/ melampirkan OE/HPS sebagai acuan melakukan negoisasi baik harga maupun kualitas barang/jasa yang dibutuhkan.

\section{Peran Guru Dalam Administrasi Keuangan Sekolah}

Penanggung jawab biaya pendidikan adalah kepala sekolah namun demikian, guru diharapkan ikut berperan dalam administrasi biaya ini meskipun menambah beban mereka, juga memberikan kesempatan untuk ikut serta mengarahkan pembiayaan itu untuk perbaikan proses belajar mengajar.

Administrasi keuangan meliputi kegiatan perencanaan, penggunaan, pencatatan data, pelaporan dan pertanggung jawaban dana yang dialokasikan untuk penyelenggaraan sekolah. Tujuan administrasi ini adalah untuk mewujudkan suatu tertib administrasi keuangan, sehingga pengurusannya dapat dipertanggung jawaban sesuai dengan ketentuan yang berlaku.

Beberapa peran guru dalam administrasi keuangan ini meliputi hal-hal sebagai berikut:

a. Membuat file keuangan sesuai dengan dana pembangunan.

b. Membuat laporan data usulan pembayaran gaji, rapel ke Pemerintah Kota.

c. Membuat pembukuan penerimaan dan penggunaan dana pembangunan.

d. Membuat laporan dana pembangunan pada akhir tahun anggaran.

e. Membuat laporan Rancangan Anggaran Pendapatan Bantuan Sekolah (RAPBS).

f. Membuat laporan tribulan dana Bantuan Operasional Sekolah (BOS).

g. Menyetorkan pajak PPN dan PPH.

h. Membagikan gaji atau rapel.

i. Menyimpan dan membuat arsip peraturan keuangan sekolah.

\section{KESIMPULAN}

Keuangan adalah semua hak milik organisasi,lembaga atau instansi yang dapat dinilai uang, termasuk didalamnya barang yang dapat dinilai dengan uang dan dapat alat pembayaran Negara. Manajemen keuangan merupakan salah satu substansi manajamen sekolah yang akan turut menentukan berjalannya kegiatan pendidikan di sekolah. Sebagaimana yang terjadi di substansi manajemen pendidikan pada umumnya, kegiatan manajemen keuangan dilakukan melalui proses perencanaan, pengorganisasian, pengarahan, pengkoordinasian, pengawasan atau pengendalian. Penanggung jawab biaya pendidikan adalah kepala sekolah namun demikian, guru diharapkan ikut berperan dalam administrasi biaya ini meskipun menambah beban mereka, juga memberikan kesempatan untuk ikut serta mengarahkan pembiayaan itu untuk perbaikan proses belajar mengajar.

\section{Daftar Pustaka}

Afriansyah, H. (2019). Administrasi Keuangan. Padang:OSF.io. 
Kumalasari, D. A. (2014). Perancangan Sistem Informasi Administrasi Keuangan Sekolah Berbasis Multiuserpada Madrasah Tsanawiyahal Uswah Bergas. JurnalMahasiswa STEKOM Semarang . Rusmawati, V. (2013). PERAN KEPEMIMPINAN KEPALA SEKOLAH
DALAM UPAYA MENINGKATKAN DISIPLIN KERJA GURU PADA SDN 018 BALIKPAPAN. Journal Administrasi Negara . Wijaya, D. (2013). Implikasi Manajemen Keuangan Sekolah Terhadap Kualitas Pendidikan.

David

Wijaya 